\title{
Compliance With The Use of Personal Protective Equipment Against The Transmission of Covid-19 in Medical Personnel
}

\author{
${ }^{1}$ Sesilia Fransiska, ${ }^{2}$ Dewi Purnamawati \\ ${ }^{1}$ Family Medical Center Hospital \\ Raya Bogor St, KM.51, Ciluar, Bogor, West Java, 16710 \\ ${ }^{1,2}$ Faculty of Public Health, Muhammadiyah University of Jakarta \\ K.H. Ahmad Dahlan St, Cireundeu Ciputat, South Jakarta, 15419 \\ E-mail: sesiliafransiskamd@gmail.com
}

\begin{abstract}
Hospitals are included in the criteria for workplaces with hazards that can have an impact on health, both for health workers as well as for visitors and hospital patients, especially during the COVID-19 pandemic. Therefore, compliance and completeness of the use of PPE, especially in the Covid19 isolation room is very important. This research is a descriptive observational study, with a population and sample of 16 people. The survey was conducted using a developed questionnaire. Data collection was carried out using instruments in the form of questionnaires and observation checklist sheets. The survey was conducted using a developed questionnaire. Compliance and completeness of the use of PPE for inpatients in COVID-19 isolation at FMC Hospital is 100\%. The respondents which are medical staff use complete level 3 PPE which consists of eye protection and face shield, head cover/head cap, N95 mask or equivalent, Coverall / Gown/apron, sterile rubber surgical gloves disposable, boots/rubber boots. But the incidence of COVID-19 transmission is $40 \%$ for inpatients medical staff in isolation for COVID-19. The possibility of transmission does not come from the workplace but can occur in daily routines and social activities. Compliance and completeness in the use of PPE for inpatients in COVID-19 isolation in FMC Hospital are high (100\%), the incidence of being infected with COVID-19 in medical personnel does not only occur in the work environment.
\end{abstract}

Keywords: personal protective equipment (PPE), compliance, completeness of PPE, hospital, COVID19 


\section{INTRODUCTION}

A hospital is a place of service with various kinds of diseases including infectious diseases, ranging from mild to severe. This will increase the risk of spreading the infection from one patient to another. Transmission of the infection can be through several ways, can be from the air, blood, or body fluids (Siegel et al., 2007).

Occupational health and safety is an effort to provide safety guarantees and improve the health status of workers by preventing accidents and occupational diseases, controlling hazards in the workplace, health promotion, treatment, and rehabilitation. (Ministry of Health, 2010). In-Law No. 26 of 2009 concerning Health, Article 23 states that Occupational Health and Safety efforts must be carried out in all workplaces, especially workplaces that have health risks, are susceptible to disease, or have at least 10 employees. Hospitals are included in the criteria for workplaces with hazards that can have an impact on health, both for health workers and for visitors and hospital patients. So that Occupational health and safety efforts must be carried out by hospitals (Indonesian Ministry of Health, 2016). One of the causes of disease exposure from patients to medical personnel is the indiscipline of medical personnel in implementing compliance with the use of Personal Protective Equipment (PPE). In the hospital, several people work simultaneously, interacting directly or indirectly with patients who are hospitalized (Diri et al., 2018).

At the end of December 2019, a case of pneumonia of unknown etiology was reported. On January 7, 2020, China identified pneumonia of unknown cause as a new type of Coronavirus (Sars$\mathrm{CoV}$ 2) as a mutation of the SARS and Mers-CoV-2 viruses. On January 30, 2020, the World Health Organization (WHO) declared this novel coronavirus pneumonia a Public Health Emergency of International Concern (PHEIC), and on March 11, 2020, WHO declared COVID-19 a global pandemic. As of April 20, 2021, the number of cases worldwide has reached 141,000,000 cases, with $3,010,000$ deaths, and 80,400,000 recoveries. The highest number of cases was in the United States at 31.8 million, followed by India with 15.1 million. Indonesia is ranked 18th in the world rankings.

On March 16, 2020, the Family Medical Center Hospital issued a Circular regarding the announcement of the COVID-19 pandemic in Indonesia. Starting with eliminating visiting hours, screening before entering the hospital, and using PPE for every medical worker who works.

Seeing the high risk of exposure to the COVID-19 virus to medical personnel on duty in the COVID isolation room, it is necessary to pay attention to the hospital management to make a policy to prevent the spread of the COVID-19 virus which can interfere with the health of doctors and nurses who work. in the COVID isolation room. Discipline and obedience of medical personnel in using PPE are important, depending on intrinsic and extrinsic motivation (Panaha et al., 2021).

Therefore, during the COVID-19 outbreak period, the implementation of infection prevention and control (PPI) is very important in health services, and the protection of medical personnel is a priority 
for the FMC Hospital, especially for medical personnel serving in the COVID-19 isolation room (Panaha et al., 2021; Supriyatiningsih \& Rosa, 2015).

\section{METHODS}

This research was conducted in the COVID-19 isolation work area of the Family Medical Center Hospital located on the Jakarta Bogor highway KM 51, Ciluar, Bogor, in March - April 2021. The population and sample were all medical personnel including doctors and nurses who worked in the isolation room. COVID-19 at the Family Medical Center Hospital, totaling 16 people.

The design of this study was carried out to obtain correlation information between the discipline of using PPE for medical officers and the chance of contracting Covid-19 for the medical staff themselves. This research is descriptive observational. The survey was conducted using a developed questionnaire. Data collection was carried out using instruments in the form of questionnaires and observation checklist sheets. The variables studied in this study consisted of age, gender, last education, length of work, completeness of PPE, compliance with using PPE, and the incidence of being infected with COVID-19.

\section{RESULTS AND DISCUSSION}

Overall, the characteristics of the respondents in this study can be seen in Table 1. which shows that as many as 13 people $(81.25 \%)$ are in the age group $>25$ years, and as many as 3 people $(18.75 \%)$ are in the age group $<25$. year. Based on the gender of the respondent. The gender characteristics of the respondents were divided into male and female, it is known that the research respondents amounted to 16 people, consisting of 7 people (43.75\%) male and 9 people $(56.25 \%)$ female. Then based on services for COVID-19 isolation inpatients, consisting of the nurse and doctor professions. There are 9 nurses (56.25\%), and 7 doctors (43.75\%).

For the education group, the results showed that 8 people $(50 \%)$ of the respondents were in the diploma education group, mostly nurses. Then 8 people $(50 \%)$ with the last education level Bachelor. Then for the length of service, the results showed that as many as 13 people $(81.25 \%)$ were in the group with a working period of fewer than 5 years, while as many as 3 people $(18.75 \%)$ were in the group with a working period of more than 5 years. Furthermore, for compliance with using PPE, the results showed that $100 \%$ of respondents were obedient in using PPE. And then for the completeness of the use of PPE the results of the study show that $100 \%$ of respondents use complete level 3 PPE which consists of eye protection and face shield, head cover/head cap, N95 mask or equivalent, Coverall / Gown/apron, sterile rubber surgical gloves disposable, boots/rubber boots. 
Table 1. Characteristics of respondents based on age, gender, profession, education, and work experience on compliance and completeness of the use of PPE

\begin{tabular}{|c|c|c|c|c|c|c|c|}
\hline \multirow[t]{2}{*}{ Variable } & \multirow[t]{2}{*}{ Category } & \multirow[t]{2}{*}{$\mathbf{n}$} & \multirow[t]{2}{*}{$\%$} & \multicolumn{2}{|c|}{$\begin{array}{c}\text { Compliance with the use of PPE } \\
(\%)\end{array}$} & \multicolumn{2}{|c|}{$\begin{array}{c}\text { Completeness of the use of PPE } \\
(\%)\end{array}$} \\
\hline & & & & Conforming & Nonconforming & Conforming & Nonconforming \\
\hline \multirow{2}{*}{$\begin{array}{l}\text { Age } \\
(\text { years })\end{array}$} & $<25$ & 3 & $18,75 \%$ & $100 \%$ & - & $100 \%$ & - \\
\hline & $\geq 25$ & 13 & $81,25 \%$ & $100 \%$ & - & $100 \%$ & - \\
\hline \multirow[t]{2}{*}{ Gender } & Man & 7 & $43,75 \%$ & $100 \%$ & - & $100 \%$ & - \\
\hline & Woman & 9 & $56,25 \%$ & $100 \%$ & - & $100 \%$ & - \\
\hline \multirow{2}{*}{$\begin{array}{l}\text { Type of } \\
\text { Profession }\end{array}$} & Nurses & 9 & $56,25 \%$ & $100 \%$ & - & $100 \%$ & - \\
\hline & Doctors & 7 & $43,75 \%$ & $100 \%$ & - & $100 \%$ & - \\
\hline \multirow[t]{2}{*}{ Education } & Diploma & 8 & $50 \%$ & $100 \%$ & - & $100 \%$ & - \\
\hline & Bachelor & 8 & $50 \%$ & $100 \%$ & - & $100 \%$ & - \\
\hline \multirow{2}{*}{$\begin{array}{l}\text { Length of } \\
\text { works } \\
\text { (years) }\end{array}$} & $<5$ & 13 & $81,25 \%$ & $100 \%$ & - & $100 \%$ & - \\
\hline & $\geq 5$ & 3 & $18,75 \%$ & $100 \%$ & - & $100 \%$ & - \\
\hline
\end{tabular}

COVID-19 can be transmitted through small droplets from the nose or mouth when coughing or sneezing. The droplets then fall on nearby objects. If someone else touches an object that has been contaminated with these droplets, then that person touches the eyes, nose, or mouth (triangle of the face), then that person can be infected with COVID-19. Or it could be that someone is infected with COVID-19 when they accidentally inhale droplets from an infected person. This is why we need to keep a distance of approximately one meter from sick people. The results of the study show that as many as 6 people (37.5\%) have been infected with COVID 19, while the remaining 10 people (62.5\%) have not been infected with COVID-19. This is by research from Apriningsih regarding the Prevention of COVID-19 Transmission in Health Workers at Sebelas Maret University Hospital. Where in the analysis of the problem said that lack of awareness of transmission among nurses, lack of knowledge about transmission and good personal protective equipment, stress and anxiety in nurses, and lack of hospital management support are the root causes of COVID-19 transmission in health workers (Apriningsih, 2020 ).

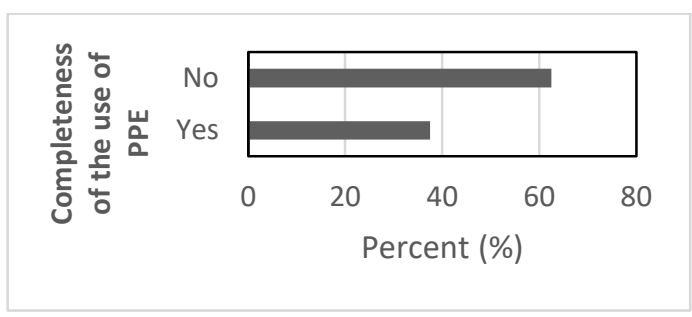

Graph 1: Incidence of being Infected with COVID-19

Complete compliance with the use of PPE for health workers who handle COVID-19 can reduce COVID 19 infections for health workers who treat COVID-19 patients (Panaha et al., 2021; Supriyatiningsih \& Rosa, 2015). However, the interesting data shown by graph 2 below, believe the relationship between compliance and completeness of PPE with the incidence of being infected with 
COVID-19 in medical workers. Even though the compliance and completeness of medical personnel have been implemented $100 \%$ by inpatient medical personnel in the isolation of COVID-19 at FMC Hospital, there are still 40\% cases the medical personnel infected by COVID-19 (Graph 1). With the protection provided by PPE, medical staff who handles patients in the isolation of COVID-19 at the FMC Hospital should not experience the occurrence of COVID-19. Thus, the chance of being infected with COVID-19 for medical personnel does not only occur in the work environment but can occur in daily routines and social activities (Apriningsih, 2020).

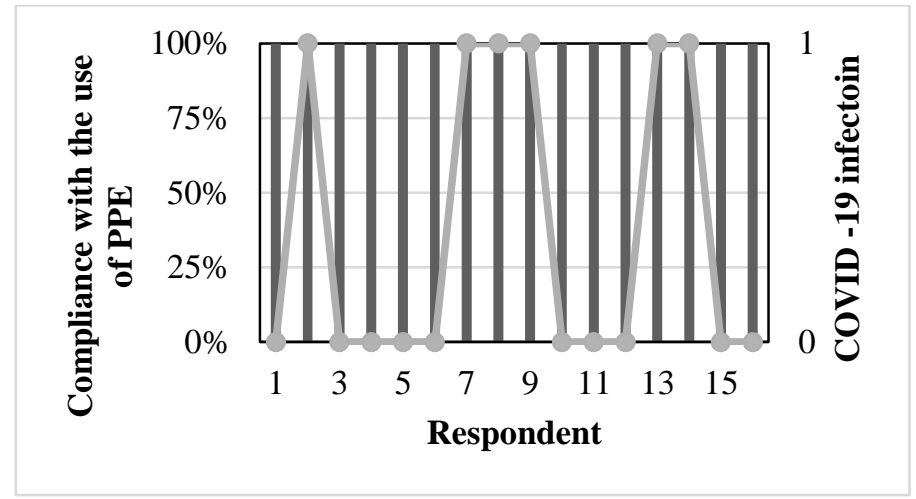

Graph 2: The Relationship between Compliance with the use of PPE, The Completeness of PPE with The Incidence of being Infected witAh COVID-19

\section{CONCLUSION AND SUGGESTIONS}

As many as $81.25 \%$ of respondents are in the age group 25 years, $56.25 \%$ are female, $56.25 \%$ are nurses, for D3 and S1 education have the same value 50\%, and $81.25 \%$ have years of service below 5 years.

All respondents are obedient and complete in using PPE (100\%), but there have been incidents of being infected with COVID-19. Thus, the chance of being infected with COVID-19 for medical staff does not only occur in the work environment but can occur in daily routines and social activities. Analysis using chi-square cannot be done, because the results of research data on compliance and completeness of the use of PPE are $100 \%$.

The Hospital Infection Control Prevention Committee needs creative and continuous efforts so that staff compliance, especially doctors and nurses, is maintained. In this case, by increasing monitoring efforts, warnings from colleagues/superiors, PPI socialization about the use of PPE. For hospitals, the availability of PPE is also important, considering that the completeness of the use of PPE, especially level 3 is quite a lot so that the completeness of PPE is maintained to protect medical officers, especially COVID-19 isolation inpatients. For further research, it is recommended that the sample used in the study is wider, and more variables so that the research results are maximized. 


\section{REFERENCES}

Apriningsih, H. et al. (2020). Prevention of Transmission of Covid-19 in Health Workers in. Jurnal Ilmiah Pengabdian Kepada Masyarakat, 4(2).

Diri, P., Di, A. P. D., \& Kariadi, R. (2018). Faktor-Fakto Yang Berhubungan Dengan Tingkat Kepatuhan Perawat Terhadap Penggunaan Alat Pelindung Diri (Apd) Di Rsup Dr. Kariadi Semarang (Studi Kasus Di Instalasi Rawat Inap Merak). Jurnal Kesehatan Masyarakat (eJournal), 6(1), 800-808.

Panaha, M. M., Maramis, F. R. R., Kesehatan, F., Universitas, M., Ratulangi, S., Kesehatan, P., Perawat, K., \& Perawat, M. (2021). 16 tinjauan sistematis hubungan motivasi kerja dengan kepatuhan penggunaan alat pelindung diri (apd) pada perawat di rumah sakit. 10(4), 16-23.

Sari, L. (2021). Gambaran risiko k3rs di rumah sakit muhammadiyah palembang selama masa pandemi covid-19. 1-5.

Siegel, J. D., Rhinehart, E., Jackson, M., \& Chiarello, L. (2007). 2007 Guideline for Isolation Precautions: Preventing Transmission of Infectious Agents in Health Care Settings. American Journal of Infection Control, 35(10), S65-S164. https://doi.org/10.1016/j.ajic.2007.10.007

Supriyatiningsih, N. S., \& Rosa, E. M. (2015). JMMR: jurnal medicoeticolegal dan manajemen rumah Sakit. JMMR (Jurnal Medicoeticolegal Dan Manajemen Rumah Sakit), 4(1), 1-19. http://journal.umy.ac.id/index.php/mrs/article/view/978/1067

Indonesian Ministry of Health, 2010. Health and Safety Standards at Home Sick. Directorate of Occupational Health Development.

Indonesian Ministry of Health, 2016. No. 66 Occupational Health and Safety in Hospitals. Task Force for the Acceleration of Handling COVID-19. 2020. Standards for Personal Protective Equipment (PPE) for Handling COVID-19 in Indonesia.

Director-General of Health Services. 2020. Technical Instructions for the Use of Personal Protective Equipment (PPE) in Facing the COVID-19 Outbreak. 